\title{
Barns rett til beskyttelse i foreldretvister om samvær - hvilken innflytelse har Rt. 2013 s. 1329 hatt på lagmannsrettspraksis?
}

Malin Karlsen og Kristin Skjørten

Malin Karlsen fullførte mastergraden i rettsvitenskap høsten 2017. Hun studerer nå kriminologi ved Universitet i Oslo. Kristin Skjørten er professor II ved Institutt for offentlig rett ved Universitetet i Oslo, og forsker I ved Nasjonalt kunnskapssenter om vold og traumatisk stress. ${ }^{1}$

E-post: malin.karlsen@student.jus.uio.no og krskjor@jus.uio.no (kristin.skjorten@nkvts.no)

\section{Sammendrag}

Barneloven har blitt endret flere ganger de senere år med formål om å styrke barneperspektivet i foreldretvister og gi barn фkt beskyttelse mot vold og overgrep. I 2013 avsa Hфyesterett en dom som gikk langt i å nekte far samvar med sin fem år gamle datter, sammenlignet med tidligere høyesterettsdommer hvor risiko for overgrep har vart et tema for vurderinger av samvar. I hфyesterettsdommen fra 2013 blir også flere momenter fra senere års lovendringer lagt til grunn for avgjørelsen. I denne artikkelen ser vi narmere på hvilken innflytelse denne dommen har fått for senere lagmannsrettspraksis i saker med påstander om vold eller overgrep.

Nøkkelord: barneloven, samvær, høyesterettsavgjørelser som prejudikat, foreldretvister samværsrett, Rt. 2013 s. 1329

\section{Innledning}

I domstolshierarkiet representerer avgjørelser fra Høyesterett den tyngste rettslige autoritet $\mathrm{i}$ løsningen av saker. Høyesterett skal blant annet sørge for en riktig endelig avgjørelse i en sak, gi rettsavklaring i spørsmål der gjeldende rett er uklar, og skape prejudikater til veiledning for

\footnotetext{
${ }^{1}$ Artikkelen har mottatt støtte fra publiseringstipendet ved NKVTS forskningsprogram om vold i nære relasjoner (Finansiert av Justis- og beredskapsdepartementet.)
} 
fremtidige saker. Dette innebærer også at Høyesterett bidrar til rettsutvikling på ulike lovområder. Prejudikatvirkningene av en høyesterettsavgjørelse kan imidlertid variere, og dette gjelder særlig i sakstyper som beror på dommerskjønn. ${ }^{2}$

I foreldretvister etter barneloven følger det direkte av Grunnloven $§ 104$ (2), FNs barnekonvensjon art. $13 \mathrm{nr} .1 \mathrm{og}$ barneloven $\S 48$ at avgjørelsene skal treffes ut fra hensynet til det som er best for det enkelte barn i den konkrete saken. I sin kommentarutgave til barneloven fremholder Backer at saker om foreldreansvar, fast bosted og samvær er eksempler på sakstyper der avgjørelser for Høyesterett $i k k e$ kan tjene som prejudikater i streng forstand, men bare angi hvilke momenter som kan være relevante $\mathrm{i}$ «barnets beste»vurderinger og vise hvordan ulike hensyn kan veies mot hverandre. ${ }^{3}$ I tillegg er det svært få foreldretvister som blir behandlet på dette domstolsnivået. De aller fleste saker som ankes til Høyesterett, blir avvist. Dette betyr at vi ikke kan avlede rettstilstilstanden på lavere rettsnivå med utgangspunkt i høyesterettsavgjørelser i saker etter barneloven. Hvilken innflytelse avgjørelser fra Høyesterett faktisk har for underrettene i disse sakene, er et empirisk spørsmål. Så langt vi vet, har ikke dette blitt undersøkt tidligere. I denne artikkelen belyser vi dette spørsmålet med utgangspunkt i en høyesterettsdom fra 2013 hvor et sentralt spørsmål var om samvær skulle nektes ut fra påstander om seksuelle overgrep. I den videre analysen går vi gjennom et utvalg lagmannsrettsdommer der denne høyesterettsdommen vises til. ${ }^{4}$

Fra 1994 og frem til i dag har det blitt avsagt fem Høyesterettsdommer som har omhandlet foreldretvister om samvær i saker med påstander om vold og overgrep. ${ }^{5}$ I den siste av disse dommene, Rt. 2013 s. 1329, blir flere av de sentrale momentene som er fremmet i forarbeidene, lagt til grunn for avgjørelsen. ${ }^{6}$ Det var særlig to av barnelovens forarbeider som stod sentralt i denne dommen: Ot.prp. nr. 103 (2004-2005) og Prop. 85 L (2012-2013). Disse

\footnotetext{
2 Backer, I.L. (2017a), «Den øverste domstols oppgaver», referat fra forhandlinger fra det 41. nordiske juristmøte. http://nordiskjurist.org/wpcontent/uploads/2018/11/Lorange_Backer_Inge_Den_overste_domst_oppgaver.pdf http://www.confedentevents.fi/njm2017/referat/

${ }^{3}$ Backer, I.L. (2017b) Barneloven. Kommentarutgave. 2. utgave, 2. opplag. Universitetsforlaget, s. 337. Lignende synspunkter fremgår også av Bendiksen. L.R.L. og Haugli, T. (2015), Sentrale emner i barneretten. Universitetsforlaget. 2. utgave, s. 33.

${ }^{4}$ Artikkelen bygger videre på avhandlingen til Malin Karlsen: Barns rett til beskyttelse i foreldretvister om samvær. Betydningen av Rt. 2013 s. 1329 i lagmannsrettspraksis fra 2016-2017. Masteravhandling i rettsvitenskap, Juridisk fakultet, Universitetet i Oslo, høsten 2017.

${ }^{5}$ Rt. 1994 s. 1394, Rt. 1996 s. 888, Rt. 2010 s. 216, Rt. 2011 s. 1572 og Rt. 2013 s. 1329.

${ }^{6}$ Det er hittil (juli 2018) ikke avsagt noen ny høyesterettsdom som behandler spørsmålet om samværsrett i foreldretvister med påstander om vold og overgrep.
} 
forarbeidene foreslo flere endringer i barneloven som har til hensikt å gi barn $\emptyset \mathrm{kt}$ beskyttelse mot vold og overgrep og styrke deres rett til å bli hørt.

Rt. 2013 s. 1329 blir ofte vist til i underrettene når risiko for overgrep er et tema i foreldretvister. I vårt utvalg av saker for lagmannsrettene hvor denne dommen ble vist til, var det i tilknytning til vurderinger av samværsspørsmål. Vi avgrenser derfor artikkelen til å gjelde samværsspørsmålet i foreldretvister.

\section{Rettslig utgangspunkt for vurderinger av samvær}

FNs barnekonvensjon tar som utgangspunkt at samvær mellom foreldre og barn er viktig og verdifullt, og barnekonvensjonen artikkel $9 \mathrm{nr} .3$ fastsetter at et barn som er atskilt fra en eller begge foreldre, har rett til «å opprettholde personlig forbindelse og direkte kontakt med begge foreldrene regelmessig, med mindre dette er i strid med barnets beste». ${ }^{7}$ Også barneloven tar som utgangspunkt at barn har rett til samvær med begge foreldre, jf. bl. § 42. Om foreldrene ikke bor sammen, har den av foreldrene barnet ikke bor fast hos, lovfestet rett til samvær etter bl. $\S 43$ første ledd første punktum. Dersom foreldre ikke blir enige i spørsmålet om samvær, kan de reise sak for domstolen.

Barnets beste skal legges til grunn for avgjørelsene, og det følger av bl. § 48 annet ledd at retten må ta hensyn til at barnet ikke må «bli utsatt for vald eller på anna vis bli handsama slik at den fysiske eller psykiske helsa vert utsett for skade eller fare». Denne presiseringen kom inn i barneloven med lovendringen i 2006, og pålegger retten en plikt til å vektlegge at barnet ikke må bli utsatt for skade eller fare. Etter bl. $§ 43$ annet ledd foreligger det også en plikt til å høre hva barnet mener, og vektlegge dette i samsvar med reglene i bl. $\S 31$ annet ledd. Dette gjelder enten det er foreldrene som inngår avtale, eller det er domstolen som skal avgjøre spørsmålet. Videre følger det av bl. § 43 annet ledd at det skal legges vekt på hensynet til best mulig samlet foreldrekontakt, barnets alder, barnets tilknytning til nærmiljøet, reiseavstand mellom foreldrene og hensyn til barnet ellers ved avtale eller avgjørelse om samværets omfang. Disse momentene ble også tilføyd ved lovendring i $2006,{ }^{8}$ og var ment mer som en presisering enn som en endring av rettspraksis.

\footnotetext{
${ }^{7}$ Sitert fra den norske oversettelsen som er tilgjengelig på https://www.regjeringen.no/globalassets/upload/kilde/bfd/bro/2004/0004/ddd/pdfv/178931fns_barnekonvensjon.pdf

${ }^{8}$ Endringslov 7. april 2006 nr. 6.
} 
Ved samme lovendring fikk også bl. § 43 en ny tilføyelse, og det fremgår nå av første ledd tredje punktum at dersom samvær ikke er til barnets beste, skal samvær nektes. Dette skal bidra til å gjennomføre barnekonvensjonen art. 19 nr. 1 i norsk rett. Tilføyelsen tar særlig sikte på situasjoner hvor barnet har vært eller er i fare for å bli utsatt for overgrep. ${ }^{9}$ Ved vurderinger av om samvær vil være til barnets beste, fremgår det av forarbeidene at det skal legges vekt på overgrepets omfang og art, skadevirkninger for barnet, og om overgrepene har fått konsekvenser for bostedsforelderens omsorgsevne. ${ }^{10}$ Dersom bostedsforelderen og barnet bor på sperret adresse eller har fiktiv identitet, skal samvær nektes. Dette begrunnes med at et eventuelt samvær kan føre til at beskyttelsestiltakene mister sin virkning. ${ }^{11}$

Tidligere rettspraksis viste at Høyesterett i en rekke dommer fastholdt at det skulle «ganske tungtveiende grunner» til for å nekte samvær. ${ }^{12}$ I Prop. 85 L (2012-2013) fastslås det imidlertid at «tungtveiende grunner» ikke skal forstås som et tilleggsvilkår når det skal treffes avgjørelser om samvær. ${ }^{13}$ I samme lovforarbeid forutsettes det også at domstolen i større grad skal avgjøre samværssaker ut fra forholdene her og nå, og at barnets subjektive opplevelser skal gis større vekt. ${ }^{14}$

Ved lovendring i 2013 fikk barneloven tilføyd en ny bestemmelse om samvær, § 43a. Etter denne kan retten fastsette samvær under tilsyn av offentlig oppnevnt person, hvor staten har ansvaret for gjennomføringen av tilsyn og dekker kostnadene ved dette. Denne ordningen er tiltenkt saker hvor det foreligger risiko ved samvær, samtidig som et avgrenset samvær med tilsyn vurderes å være til barnets beste. Med barneloven $\S 43$ a fikk vi en ny, todelt tilsynsordning. Beskyttet tilsyn er tiltenkt saker hvor samværsforelderen har volds- eller rusproblemer eller psykiske problemer som kan påvirke omsorgsevnen, men hvor det likevel vil være til barnets beste med begrenset samvær. Beskyttet tilsyn kan idømmes for inntil 16 timer i året, og barneverntjenesten er ansvarlig for gjennomføringen. En tilsynsperson skal være til stede under hele samværet. Støttet tilsyn har en maksimumsramme på 32 timer i året. Retten kan imidlertid fastsette mer samvær, og da vil kun deler av samværet være med tilsyn. Formålet er å veilede foreldre og gi støtte til barnet i en overgangsfase mot samvær uten tilsyn.

\footnotetext{
${ }^{9}$ Ot.prp. nr. 103 (2004-2005) Om lov om endringer i barnelova mv. (Omfanget av samvær, styrking av meklingsordningen, tiltak for å beskytte barn mot overgrep, foreldreansvar etter dødsfall, tilbakebetaling av barnebidrag mv.) s. 54.

10 Ibid., s. 54.

11 Ibid., s. 54 .

12 Se f.eks. Rt. 2010 s. 216, Rt. 2007 s. 967 og Rt. 1996 s. 888.

${ }^{13}$ Prop. 85 L (2012-2013) Endringer i barnelova (barneperspektivet i foreldretvister), s. 43.

14 Ibid., s. 6.
} 
Barne-, ungdoms- og familiedirektoratet har ansvaret for gjennomføringen, og ordningen er tiltenkt saker med store konflikter mellom foreldre, og saker der det er behov for støtte til kontaktetablering mellom barnet og samværsforelderen. Ved samme lovendring ble den tidligere bestemmelsen om adgang til å fastsette privat tilsyn opprettholdt. Her dekkes utgiftene av samværsforelderen, og foreldrene må selv finne frem til en tilsynsperson.

\section{Kort om Rt. 2013 s. 1329}

I sammendraget av dommen fra Lovdata kan vi lese:

«I sak om samvær kom Høyesterett til at far ikke skulle ha samvær med en fem år gammel datter, jf. barneloven $\S 43$ første ledd tredje punktum. Han hadde vært siktet for seksuell omgang med mors særkullsbarn, men saken var henlagt etter bevisets stilling. Det var ikke omstendigheter ved ham som utelukket et begrenset samvær under tilsyn. Konfliktnivået mellom foreldrene var imidlertid høyt. Det ble vist til at det ikke lot seg gjøre å avkrefte risiko for overgrep, og lagt avgjørende vekt på at samvær ville medføre en åpenbar belastning for mor, og dermed også for fellesbarnets omsorgssituasjon. Denne belastningen ville overstige gevinsten ved av og til å møte far.»

Dommen dreide seg om fars samværsrett med sin fem år gamle datter. Far hadde i 2009 blitt siktet for seksuell omgang med mors særkullsbarn. Politiet hadde henlagt saken på grunn av bevisets stilling, men jenta hadde senere fått tilkjent oppreising fra Voldsoffererstatningskontoret som fant det klart sannsynliggjort at overgrep hadde skjedd. Det var høyt konfliktnivå mellom partene i saken, og siktelsen mot far i 2009 var årsaken til samlivsbruddet mellom dem.

Mor hevdet at fars rett til samvær med datteren måtte vike for hensynet til at barnet skulle få god omsorg i hverdagen fra en stabil og trygg omsorgsperson. ${ }^{15}$ Far anførte at det ikke forelå omstendigheter som tilsa at samvær ikke ville være til datterens beste. ${ }^{16}$

Tidligere samvær mellom far og datter hadde etter det retten fikk opplyst, fremstått som positive for datteren. Retten kunne heller ikke se at det var omstendigheter ved far som tilsa at

\footnotetext{
${ }^{15}$ Rt. 2013 s. 1329 , premiss 27.

16 Ibid., premiss 18.
} 
samvær måtte nektes. ${ }^{17}$ Dommerne mente videre at ansvaret for konflikten mellom foreldrene ikke kunne legges på den ene av partene. Det forelå heller ikke grunnlag for å mene at den ene forelderen ivaretok datteren bedre enn den andre, men konflikten mellom dem hadde ført til lite konstruktive utspill fra begge. ${ }^{18}$

Mor anførte at hennes vegring med hensyn til samvær bunnet i særkullsbarnets opplysninger om at stefar hadde utsatt henne for overgrep, og usikkerheten hun hadde for at deres felles datter også kunne bli utsatt for overgrep. Retten mente at det ikke kunne legges til grunn tilstrekkelig grad av sannsynlighet for at far hadde begått overgrep mot stedatteren, eller at han ville begå overgrep mot datteren. ${ }^{19}$ Likevel kom Høyesterett frem til at det ikke skulle fastsettes samvær mellom far og datter. I tråd med flertallets uttalelse fra lagmannsretten mente Høyesterett at samvær ville medføre en åpenbar belastning for mor, som igjen ville gå ut over jentas omsorgssituasjon, fordi det ikke lot seg gjøre å avkrefte at det forelå risiko for overgrep. I denne saken har mor diagnosen multippel sklerose og ble ansett som særlig sårbar for belastninger og press. Høyesterett konkluderte med at samvær måtte nektes. ${ }^{20}$

Far ønsket en opptrappingsplan med samvær under tilsyn, som etter hvert kunne gå over i samvær uten tilsyn. Etter rettens mening kunne det ikke gis dom for en slik samværsrett, fordi det bygget på et for usikkert grunnlag. ${ }^{21}$

\section{De sentrale momentene i høyesterettsdommen}

Høyesterettsdommen gikk langt i å nekte samvær mellom far og datter, sammenlignet med tidligere praksis. Førstvoterende kom med noen prinsipielle uttalelser og bekreftet flere av de momentene som er fremhevet i Ot.prp. nr. 103 (2004-2005) og Prop. 85 L (2012-2013). De sentrale momentene som ble lagt til grunn for samværsnekt, utdypes nedenfor.

\subsection{Barneloven $§ 43$ første ledd, tredje punktum - en absolutt regel}

Ved lovendring i 2006 fikk som nevnt bl. § 43 tilføyd et nytt første ledd tredje punktum der det heter at «[d]ersom samvær ikkje er til beste for barnet, må retten avgjere at det ikkje skal vere samvær». Førstvoterende i høyesterettsdommen viser til denne regelen, og legger til at

\footnotetext{
17 Ibid., premiss 42 jf. premiss 45.

${ }^{18}$ Rt. 2013 s. 1329 premiss 43.

${ }^{19}$ Ibid., premiss 44-45.

20 Ibid., premiss 48-50.

21 Ibid., premiss 40.
} 
denne regelen er absolutt. ${ }^{22}$ I tillegg vises det til bl. $§ 48$ og barnekonvensjonen art. 3 om at det alltid skal tas hensyn til hva som er best for barnet. Førstvoterende viser videre i avsnitt 34 til særmerknadene til dette punktumet i Ot.prp. nr. 103 (2004-2005) på side 54, hvor det blant annet er uttalt:

«Det er et grunnleggende utgangspunkt at barnet skal kunne opprettholde kontakt med begge sine foreldre selv om de lever hver for seg. Det er ikke ment å endre på dette utgangspunktet. Tilføyelsen innebærer imidlertid en presisering av at det er en forutsetning for samvær at dette må anses å være til barnets beste, og tar særlig sikte på situasjoner hvor barnet har vært utsatt for, eller det er fare for at barnet vil bli utsatt for, overgrep.»

I dommen fra 2013 gis bestemmelsen i bl. $\S 43$ første ledd tredje punktum status som avgjørende fordi dommen fastslår at regelen er absolutt. Av lovteksten fremgår det at retten må avgjøre at det ikke skal være samvær dersom det ikke er til barnets beste, og Høyesteretts uttalelse om at denne regelen er absolutt, gir den en udiskutabel stilling.

\subsection{Tungtveiende grunner - moment fra lovforarbeid}

I Prop. 85 L (2012-2013) vises det til tidligere høyesterettsdommer hvor det ble lagt til grunn at det skal «ganske tungtveiende grunner» til for å nekte samvær. ${ }^{23}$ Videre vises det til barneloven $\S 43$ første ledd tredje punktum hvor det fastsettes at det ikke skal være samvær når dette ikke er til barnets beste, og ut fra dette legger forarbeidet til grunn at «ganske tungtveiende grunner» ikke må forstås som tilleggsvilkår i vurderinger av barnets beste ved samvær:

«Departementet legger til grunn at formuleringen 'ganske tungtveiende grunner' er egnet til å belyse det generelle utgangspunktet om at barn og foreldre har en samværsrett, forankret i menneskerettighetene. Det avgjørende vilkåret/hensynet skal imidlertid være barnets beste. Formuleringen 'tungtveiende grunner' skal derfor ikke forstås som en form for tilleggsvilkår eller et ekstra kriterium for når domstolen skal/bør fastsette at det ikke skal være samvær etter barneloven. Tilføyelsen av første

\footnotetext{
22 Ibid., premiss 33.

${ }^{23}$ Prop. 85 L (2012-2013) punkt 7.2.1.
} 
ledd tredje punktum i barneloven i 2006 ble foretatt nettopp for å tydeliggjøre at barnets beste skal være avgjørende i samværssaker.» ${ }^{24}$

Hensikten i lovforarbeidene med å presisere at det ikke lenger er noe krav om «tungtveiende grunner», var å bidra til å senke terskelen for når domstolen avgjør at det ikke skal være samvær. $^{25}$

I Rt. 2013 s. 1329 avsnitt 36-38 viser førstvoterende til Prop. 85 L (2012-2013) punkt 7.2.4.1 og fastslår at «tungtvegande grunnar ikkje er noko tilleggsvilkår ut over det som står i lova». ${ }^{26}$ Det eneste og avgjørende kriteriet i vurderingen av samværsspørsmålet skal være barnets beste, jf. bl. $§ 43$ første ledd tredje punktum. Med denne siste høyesterettsdommen kan vi konkludere at presedensen for å kreve «ganske tungtveiende grunner» ved vurdering av samværsnekt nå er opphevet.

\subsection{Svekket omsorgsevne hos bostedsforelderen - moment fra forarbeid}

Den klare hovedregel er at sterke motsetningsforhold mellom foreldrene ikke er til hinder for samværsrett så lenge det ikke er noe motsetningsforhold mellom barnet og den samværss $\emptyset$ kende. ${ }^{27}$ I Ot.prp. nr. 103 (2004-2005) fremheves det likevel, under merknader til bl. $§ 43$ første ledd tredje punktum, at dersom samvær reduserer omsorgsevnen hos bostedsforelderen, kan dette få betydning i vurderingene. Dette momentet blir sitert i avsnitt 35 i høyesterettsdommen:

«Dersom den som har barnet boende fast hos seg har utviklet angst i forhold til den som ønsker samvær i en slik grad at et eventuelt samvær går ut over evnen til å fungere som omsorgsperson for barnet, kan dette få betydning.» 28

I høyesterettsdommen følges dette opp ved følgende uttalelse fra førstvoterende:

«I det siterte frå Ot.prp.nr. 103 (2004-2005) og frå Rt-2007-967 er det sagt at også omstende hos den barnet bur fast hos, kan føre til at samvær må nektast.» ${ }^{29}$

I dommen ble det lagt til grunn at mor hadde sterke motforestillinger til samvær mellom far og datter. Hennes vegring var knyttet til barnets reaksjoner og den risiko samværet ville

\footnotetext{
${ }^{24}$ Ibid., punkt 7.2.4.1.

${ }^{25}$ Prop. 85 L (2012-2013) s. 41.

${ }^{26}$ Rt. 2013 s. 1329 premiss 39.

27 Backer, I.L. (2017b), s. 392.

${ }^{28}$ Ot.prp. nr. 103 (2004-2005) s. 54 og Rt. 2013 s. 1329 premiss 35.

${ }^{29}$ Rt. 2013 s. 1329 premiss 47.
} 
utgjøre for barnet. Et eventuelt samvær ville påføre mor en belastning og påvirke hennes ivaretakelse av omsorgen for barnet. Retten mener også at avgjørelsen fra Voldsofferkontoret, som fant det sannsynlig at stedatteren var utsatt for overgrep, har medvirket til mors holdning til samvær. ${ }^{30}$ Høyesterett sluttet seg til flertallsvotumet i lagmannsretten som mente at

«[d]et må etter dette legges til grunn at mor vil oppleve ethvert samvær som opprivende, og at dette vil ha negativ effekt for mors helse og slik innebære en risiko for ivaretakelse av D. Så lenge det ikke lar seg gjøre å avkrefte at det foreligger en risiko for overgrep, vil samvær medføre en åpenbar belastning for mor, og dermed også for Ds omsorgsituasjon.» ${ }^{31}$

Denne vurderingen var også i samsvar med sakkyndiges vurderinger for tingretten og lagmannsretten. Momentet fra forarbeidene om svekket omsorgsevne hos bostedsforelderen, som følge av samvær, ble tillagt avgjørende vekt i denne høyesterettsdommen.

\subsection{Risiko for overgrep - barneloven $§ 48$ annet ledd}

Annet ledd i barneloven $\S 48$, som ble tilføyd i 2006, pålegger som nevnt retten å vektlegge at barnet ikke må utsettes for vold eller annet som kan føre til skade eller fare i vurderinger av barnets beste. I Ot.prp. nr. 103 (2004-2005) utdypes innholdet i denne tilføyelsen under merknadene til de enkelte paragrafer:

«Hensikten med tilføyelsen er videre å sikre at hensynet til barnet tillegges tilstrekkelig vekt i de situasjonene hvor det er vanskelig eller umulig å ta stilling til om overgrep har skjedd eller vil komme til å skje. Hvis det er en reell risiko for at barnet blir utsatt for overgrep hos en av foreldrene, må dette få betydning for rettens avgjørelse. Det kan ikke legges vekt på enhver påstand om overgrep. Det må legges til grunn at det som utgangspunkt må foreligge forhold som underbygger påstanden.» 32

I sivile saker er det ingen generell regel etter tvisteloven ${ }^{33}$ om hvilken grad av sannsynlighet som må foreligge om et faktisk forhold for at dette skal kunne legges til grunn i avgjørelsen. Etter alminnelig enighet i norsk rettspraksis og teori synes hovedregelen å være at det skal legges til grunn sannsynlighetsovervekt, altså at retten skal legge til grunn det faktum som

\footnotetext{
${ }^{30}$ Rt. 2013 s. 1329 premiss 46.

31 Ibid., premiss 48.

32 Ot.prp. nr. 103(2004-2005) s. 56.

${ }^{33}$ Lov 17. juni 2005 nr. 90 om mekling og rettergang i sivile tvister (tvisteloven).
} 
fremstår som mest sannsynlig - mer enn 50 prosent. ${ }^{34}$ I saker etter straffeloven er beviskravene strengere, og det kreves nærmere 100 prosent sannsynlighet før et faktum legges til grunn som medfører straff. I Ot.prp. nr. 103 (2004-2005) uttrykkes bekymring for at kravene til bevis i saker etter barneloven ved mistanke om vold eller overgrep ble praktisert for strengt, og beviskravet ble justert ned med en presisering om at det kan være tilstrekkelig med mindre enn 50 prosent sannsynlighet i disse sakene:

«Det kan ikke kreves sannsynlighetsovervekt for at mistanke om vold og overgrep skal legges til grunn. Det vil også kunne være tilstrekkelig med mindre grad enn 50 prosent sannsynlighet for at beviskravet kan anses oppfylt. Hvilken grad av sannsynlighet som må foreligge vil avhenge av de konkrete omstendighetene i saken, hvor forhold som arten av overgrep det er fare for, alvorlighetsgrad og personlige forhold hos de involverte kan få betydning. Dersom det er risiko for alvorlige overgrep, vil det kunne tilsi at det skal mindre til for at beviskravet anses oppfylt.» ${ }^{35}$

Som det fremgår ovenfor i fremstillingen av saksinnholdet i høyesterettsdommen fra 2013, ble mors angst for at barnet skulle bli utsatt for overgrep, et moment som styrket argumentet om svekket omsorgsevne hos bostedsforelderen. Så lenge risiko for overgrep ikke lot seg avkrefte, ville mors angst vedvare. Dette ble utslagsgivende for avgjørelsen om at det ikke skal være samvær. Under rettens vurdering av om risiko for overgrep alene kunne være et moment for å nekte samvær, viste Høyesterett til lagmannsrettens vurderinger som lød slik:

«Far benekter å ha forgrepet seg, mens mor er overbevist om at overgrep har funnet sted slik C har forklart. Slik saken er opplyst for lagmannsretten, vil det ikke med tilstrekkelig grad av sannsynlighet kunne legges til grunn at far har forgrepet seg mot C eller at han vil begå overgrep mot D. Imidlertid legges til grunn at han ikke har begått seksuelle overgrep mot D.» ${ }^{36}$

Lagmannsretten legger med andre ord til grunn at det ikke er sterke nok bevis for at stedatteren har blitt utsatt for overgrep, og når det gjelder datteren, mener retten at far ikke har forgrepet seg på henne.

Høyesterett slutter seg til denne vurderingen:

\footnotetext{
${ }^{34}$ Ot.prp. nr. 103 (2004-2005) s. 24.

35 Ot.prp. nr. 103 (2004-2005) s. 56.

${ }^{36}$ Rt. 2013 s. 1329 premiss 44.
} 
«Lagmannsretten har kome til dette resultatet etter direkte bevisførsel, der retten har høyrt både partane og den sakkunnige. Det har ikkje kome fram noko i Høgsterett som gir meg grunnlag for å vurdere dette annleis.» ${ }^{37}$

Ofte vil det være vanskelig å bevise at et overgrep har funnet sted, og enda vanskeligere er det å avgjøre om det er fare for fremtidige overgrep. I forarbeidene er det uttalt at i saker hvor det er «like, eller også mindre, sannsynlig at det foreligger fare for overgrep», vil hensynet til at barnet ikke skal utsettes for risiko for overgrep, tale for at risikoen făr utslagsgivende effekt. ${ }^{38}$ Dersom det legges til grunn at en forelder har utsatt barnet for overgrep og dette faktisk ikke har skjedd, vil dette kunne være sterkt belastende for både forelder og barn. Likevel vil det være enda verre dersom en forelder som har utsatt eller vil utsette barnet for overgrep, får samvær. ${ }^{39}$

Hvor Høyesterett la listen for grad av sannsynlighet i vurderingen av om far hadde forgrepet seg mot stedatter, er ikke opplyst. Det som imidlertid er interessant, er at retten argumenterer med at risiko for overgrep heller ikke lar seg avkrefte. I en slik situasjon vil dette gå ut over mors omsorgsevne, og det vil ikke være til barnets beste. At risiko for overgrep ikke lar seg avkrefte, får dermed betydning for avgjørelsen om at far skal nektes samvær, fordi det styrker momentet om svekket omsorgsevne. Denne vurderingen i Rt. 2013 s. 1329 kan derfor tyde på at listen har blitt lagt lavere enn tidligere når det gjelder hvilken betydning mulig volds- og overgrepsrisiko skal tillegges i helhetsvurderinger. ${ }^{40}$

\subsection{Konkret vurdering på grunnlag av forholdene i dag - moment fra lovforarbeid}

Vurderingstemaer i saker etter barneloven står ofte i en særstilling sammenlignet med andre rettsområder. Ved avgjørelsen av slike spørsmål må den som skal treffe beslutninger, vurdere både barnets fortid og nåtid med tanke på fremtiden. Tradisjonelt har fremtidsperspektivet $\mathrm{i}$ vurderinger av barnets beste stått sterkt, og denne tidsdimensjonen har markert et skille mellom saker etter barneloven og de fleste andre saker domstolene skal ta stilling til. Dette påpekes i NOU 1998: 17:

«Til forskjell fra andre saker hvor domstolene ofte vurderer saken i et retrospektivt lys, gjelder avgjørelsene i barnefordelingssakene den fremtidige ordning for barnet. Alt

\footnotetext{
${ }^{37}$ Rt. 2013 s. 1329 premiss 45.

38 Ot.prp. nr. 103 (2004-2005) s. 29.

39 Ibid., s. 29-30.

${ }^{40}$ Se Kathrine Renate Aas (2014), Gjeldende rett om vold i samværssaker etter barneloven og barnevernloven. Masteravhandling i rettsvitenskap ved UiO, s. 25.
} 
etter barnets alder på avgjørelsestidspunktet vil avgjørelsen måtte inneholde en prognose for mange år fremover. I en slik vurdering vil det ligge skjønnsmessige elementer som kan grense til det helt usikre - ikke bare for dommeren, men også for den sakkyndige.» ${ }^{41}$

Med Prop. 85 L (2012-2013) punkt 7.2.4.1 får vi en dreining mot økt vektlegging av nåtid i vurderinger av barnets beste:

«Departementet foreslår at foreldretvister om samvær skal avgjøres i større grad ut fra barnets situasjon her-og-nå, i tråd med et styrket barneperspektiv i slike saker.»

I forarbeidet vises det til Skjørten (2010) hvor forholdet mellom fortid, nåtid og fremtid i vurderinger av barnets beste drøftes:

«Et dilemma som retten står overfor, er om avgjørelsene skal legge vekt på situasjonen her og nå, eller vurdere hva barnet er best tjent med i fremtiden. I noen saker kan det være sammenfall mellom barnets beste på kort og lang sikt. I andre saker vil det kunne reises tvil om barnets beste her og nå er i overensstemmelse med barnets beste på sikt. De sistnevnte sakene byr på problematiske avveininger om hva som er barnets beste. Bør barnet tåle påkjenninger nå fordi dette vil tjene barnet på sikt? Et barneperspektiv innebærer at barnas opplevelse av her-og-nå-situasjonen samt tidligere erfaringer får betydning i vurderinger av barnets beste. Et fremtidsorientert perspektiv på barnets beste kan være i konflikt med et barneperspektiv.» ${ }^{42}$

Hvilket tidsperspektiv som gis størst vekt i vurderinger, vil ha betydning for avgjørelsene i saker der det ikke er sammenfall mellom konklusjoner basert på fortid, nåtid og fremtid. Med $\emptyset k t$ vektlegging av situasjonen her og nå vil barnets ønsker og reaksjoner på samvær gis større tyngde i vurderingene av barnets beste.

I høyesterettsdommen fra 2013 følger førstvoterende opp lovgivers anmodning om økt vektlegging av situasjonen her og nå i den konkrete vurderingen av hvorvidt far skulle tilkjennes samvær:

\footnotetext{
${ }^{41}$ NOU 1998: 17 Barnefordelingssaker - avgjørelsesorganer, saksbehandlingsregler og delt bosted, kapittel 3. 42 Prop. 85 L (2012-2013) s. 45 (sitert fra Skjørten, K. (2010), «Barns meninger om samvær», i Kjørholt, A.T. (red.), Barn som samfunnsborgere - til barnets beste? Universitetsforlaget, s. 100).
} 
«Vurderinga må etter mitt syn skje på grunnlag av tilhøva i dag, jf. her også det som er sagt i det før nemnde punktet i Prop. 85 L.» ${ }^{43}$

Far hadde bedt om en opptrappingsplan fra samvær med tilsyn til samvær uten tilsyn. ${ }^{44}$ Høyesterett mente en slik fremtidsvurdering bygde på et for usikkert grunnlag, og ut fra forholdene her og nå ble også samvær med tilsyn vurdert til ikke å være til barnets beste.

\section{Hvilken innflytelse har Rt. 2013 s. 1329 hatt for lagmannsrettspraksis?}

Som beskrevet innledningsvis har høyesterettsdommer i barnelovsaker til dels et rettskildemessig særpreg. Ifølge Backer kan de ikke tjene som prejudikater i streng forstand, fordi avgjørelser skal treffes ut fra en konkret vurdering av hva som er det beste for det enkelte barn. ${ }^{45}$ Samtidig kan dommer fra Høyesterett ha stor betydning når det gjelder avklaring og fortolkning av lovbestemmelser, og angi hvilke momenter som kan være relevante i en «barnets beste»-vurdering.

Hvilken innflytelse Rt. 2013 s. 1329 har fått for avgjørelser på lavere rettsnivå, er et empirisk spørsmål. Vi har valgt å belyse dette ved en gjennomgang av lagmannsrettsavgjørelser hvor det har blitt vist til denne høyesterettsdommen. Vårt søk i Lovdata på lagmannsrettsavgjørelser 18. september 2017 ga 56 treff med referanse til høyesterettsdommen fra 2013. Dette viser at høyesterettsdommen ofte har blitt referert til ved behandling i lagmannsrettene av foreldretvister med påstander om vold og overgrep. Som en ytterligere avgrensning valgte vi ut dommene avsagt i 2016 og frem til utskriftsdato 18. september 2017 for en nærmere analyse. Denne avgrensningen ga totalt 16 lagmannsrettsdommer.

Av de 16 dommene er det 14 som behandler spørsmålet om det skal fastsettes samvær eller ikke, mens de to siste handler om omfanget av samvær.

I de 14 dommene hvor det ble vurdert å nekte samvær, var det kun 2 saker hvor spørsmålet var om mor skulle ha samvær eller ikke. De andre gjaldt samvær for far.

\footnotetext{
${ }^{43}$ Rt. 2013 s. 1329 premiss 40.

${ }^{44}$ Ibid., premiss 40 jf. premiss 23.

${ }^{45}$ Backer, I.L. (2017b), s. 337.
} 
I 5 av de 16 dommene ble høyesterettsdommen fra 2013 vist til i anførslene til en av partene. I 2 av disse sakene går ikke retten nærmere inn på høyesterettsdommen i sine vurderinger. I de 3 andre dommene hvor en av partene eller begge viser til høyesterettsdommen i sine anførsler, finner retten at høyesterettsdommen ikke er aktuell i den konkrete saken. I 10 dommer ble høyesterettsdommen fra 2013 referert til av lagmannsretten, uten at den ble vist til i partenes anførsler. Den siste av de 16 dommene er i en særstilling fordi høyesterettsdommen kun ble vist til under punkt 2 i mandatet til den rettsoppnevnte sakkyndige for tingretten:

«2. Du bes særlig vurdere risikoen for seksuelle overgrep fra far. [...] Retten viser også til Høyesteretts dom Rt-2013-1329, som følger vedlagt sakens dokumenter. $[\ldots] \gg^{46}$

I det følgende skal vi se på hvilke momenter fra Rt. 2013 s. 1329 som har blitt trukket frem i de 16 lagmannsrettsavgjørelsene. Som tidligere redegjort for var de sentrale momentene forholdet mellom samværsrett og barnets beste, betydningen av tungtveiende grunner, svekket omsorgsevne hos bostedforelderen, risiko for overgrep og vekting av situasjonen her og nå. I fremstillingen er lagmannsrettsdommene sortert under momentet eller momentene hvor det vises direkte til Rt. 2013 s. 1329 i dommen. Det må understrekes at flesteparten av dommene vi har gjennomgått, også vurderer andre momenter som ble behandlet i høyesterettsdommen, uten at det ble vist til Rt. 2013 s. 1329. Her ble ofte forarbeidene trukket inn under rettens vurderinger av momentene. Dette innebærer at flere dommer enn de som refereres til under de aktuelle momentene, kan ha drøftet selve momentet, uten henvisning til høyesterettsdommen.

\subsection{Barneloven $§ 43$ første ledd, tredje punktum - en absolutt regel}

I $2^{47}$ av de 16 dommene ble det vist til førstvoterendes uttalelser i Rt. 2013 s. 1329 avsnitt 33 om at retten skal fastsette at det ikke skal være samvær dersom dette ikke er til det beste for barnet, og at denne regelen i bl. $\S 43$ første ledd tredje punktum er absolutt. I begge dommene fant lagmannsretten at det ikke skulle fastsettes samvær mellom far og barn.

I den ene dommen var spørsmålet om det skulle være samvær mellom far og sønnene på henholdsvis 13 og 10 år. Far hadde tidligere opptrådt skremmende og truende. Under lagmannsrettens merknader står det:

\footnotetext{
${ }^{46}$ LB-2016-78872.

${ }^{47}$ LB-2016-152441 og LB-2015-97497.
} 
«Det foreligger imidlertid en erkjennelse av at samvær mellom foreldre og barn i enkelte tilfeller ikke er til barnets beste. Dette kommer til uttrykk i barnelova $§ 43$ første ledd siste punktum, hvor det er fastsatt at dersom samvær ikke er til beste for barnet, må retten avgjøre at det ikke skal være samvær. Dette er et påbud til retten. I Høyesteretts dom inntatt i Rt-2013-1329 er dette formulert slik at denne regelen er absolutt.» 48

I den andre dommen ${ }^{49}$ var det spørsmål om samvær mellom far og sønnen på 13 år. Gutten hadde en diagnose som gjorde ham særlig sårbar med behov for forutsigbarhet og trygge rammer. I denne dommen viste retten til to av momentene som ble tillagt vekt i høyesterettsdommen fra 2013, nemlig at det ikke foreligger et tilleggsvilkår om «tungtveiende grunner», og at regelen i bl. $\S 43$ første ledd tredje punktum er en absolutt regel:

«Det følger av barneloven $§ 43$ første ledd tredje punktum at dersom samvær ikke er til beste for barnet, 'må’ retten avgjøre at det ikke skal være samvær. I Rt-2013-1329 avsnitt 33 uttaler førstvoterende at '[d]enne regelen er absolutt'. I vår sak har partene vært noe uenige om hvorvidt det i tillegg må foreligge tungtveiende grunner for samværsnekt. I Høyesteretts sak som nevnt foran uttaler førstvoterende seg om dette etter en gjennomgang av lovforarbeider og rettspraksis. Han konkluderer med at '[t]ungtvegande grunnar ikkje er noko tilleggsvilkår ut over det som står i lova'.»

Lagmannsretten konkluderer med at det ikke skal være samvær mellom far og sønn da lovens vilkår for samværsnekt var til stede.

\subsection{Tungtveiende grunner}

Det momentet som oftest ble vist til i dommene fra lagmannsretten, var førstvoterendes uttalelse i Rt. 1329 avsnitt 39 med henvisning til Prop 85 L (2012-2013) punkt 7.2.4.1 om at «[t]ungtvegande grunnar ikkje er noko tilleggsvilkår ut over det som står i lova». I 2 av dommene ser det ut til at 2013-dommen tas til inntekt for tidligere rettspraksis der kravet for å nekte samvær var tungtveiende grunner. ${ }^{50}$ Dette er feil bruk av høyesterettsdommen fra 2013, som la til grunn at «tungtveiende grunner» faktisk ikke er noe tilleggsvilkår. I den ene av disse dommene vises det likevel til Prop. 85 L (2012-2013) punkt 7.2.4.1 hvor det presiseres at «tungtveiende grunner» ikke er noe tilleggsvilkår, og konklusjonen i denne dommen var at

\footnotetext{
${ }^{48}$ LB-2015-97497.

${ }^{49}$ LB-2016-152441.

${ }^{50}$ LF-2016-52867 og LB-2017-15997.
} 
far ble nektet samvær. ${ }^{51}$ I en tredje dom, ${ }^{52}$ som gjaldt omfang av samvær, fant retten at momentet om tungtveiende grunner for å nekte samvær hadde liten eller ingen betydning for vurderingene.

I ytterligere 6 dommer som henviste til dette momentet i høyesterettsdommen, ble momentet vurdert som relevant for saken. Her ble det kun fastsatt samvær i én av dommene. ${ }^{53}$ I de resterende 5 dommene ${ }^{54}$ kom lagmannsretten til at det forelå grunnlag for å nekte samvær. Følgende dom kan tjene som illustrasjon på argumentasjonen i disse sakene:

«Ankende part har under henvisning til Rt-1996-888 vist til at det kreves tungtveiende grunner for å nekte samvær. Lagmannsretten legger til grunn at tungtveiende grunner ikke er noe tilleggsvilkår utover det som følger av lovteksten om at retten skal nekte samvær dersom samvær ikke er til det beste for barnet. Lagmannsretten viser til Høyesteretts uttalelser om dette i Rt-2013-1329 avsnitt 39 og Rt-2010-216 avsnitt $34 .{ }^{55}$

Som tidligere nevnt skulle presiseringen av at «tungtveiende grunner» ikke kan anses som et tilleggskrav, bidra til å senke terskelen for å nekte samvær. At det bare ble fastsatt samvær i én av de 6 dommene for lagmannsrettene der dette momentet var aktuelt, kan tyde på at terskelen har blitt senket.

\subsection{Svekket omsorgsevne hos bostedsforelderen}

I $3^{56}$ av de 16 lagmannsrettsdommene vises det til avsnitt 47 eller avsnitt 48 i Rt. 2013 s. 1329, hvor det ble lagt til grunn at omstendigheter hos den barnet bor fast hos, kan føre til at samvær nektes. Den ene dommen ${ }^{57}$ gjaldt spørsmålet om det skulle fastsettes samvær mellom far og datteren på fem år. Tingretten kom til at det ikke skulle fastsettes samvær, men lagmannsretten mente at jenta skulle ha begrenset samvær med far. Det var dissens 2-1 i samværsspørsmålet. I lagmannsrettens innledende merknader refereres det til høyesterettsdommen fra 2013:

\footnotetext{
${ }^{51}$ LB-2017-15997.

52 LE-2017-32214.

${ }^{53}$ LE-2016-96445.

54 LB-2017-6107, LB-2016-152441, LB-2016-19954, LG-2015-153480 og LB-2015-76976.

55 LG-2015-153480.

${ }^{56}$ LB-2016-182791, LB-2016-14023, LE-2015-73302.

57 LB-2016-14023.
} 
«Lagmannsretten kan ikke se bort fra at reetablering av samvær mellom $\mathrm{C}$ og faren vil innebære en belastning for moren, $\mathrm{i}$ hvert fall i en periode. I en helhetsvurdering av om samvær overhode er til Cs beste, må det derfor vurderes om belastningen for B ved den fastsatte samværsordningen, blir så stor at den kan utgjøre en risiko for at hennes omsorgsevne vil bli svekket. Avgjørelser inntatt i Rt-2013-1329 er et eksempel på at dette momentet ble tillagt avgjørende vekt. I den aktuelle saken la Høyesterett til grunn at belastningen for moren ved samvær var så alvorlig at selv ikke et begrenset samvær skulle finne sted.»

Det hadde tidligere vært gjennomført samvær mellom far og datter, som hadde vakt sterke negative reaksjoner hos jenta. Det var etter lagmannsrettens mening vanskelig å ha noen klar formening om hva som var årsaken til vegring med hensyn til samvær. Flertallet mente at det ikke forelå grunnlag for å anta at samvær med tilsyn ville forstyrre jentas nå gode utvikling, og et begrenset samvær ville sikre at jenta opprettholdt kjennskap til faren og hans familie. Det ble satt som vilkår at en trygghetsperson skulle være til stede, jf. bl. § 43 (3), for at moren skulle kunne være trygg for datteren under samværene. I denne dommen ser det ut til at lagmannsretten veide hensynet til jentas kjennskap med far og hans familie tyngre enn hennes tidligere negative reaksjoner på samvær. Dommen ble imidlertid avsagt under dissens, og mindretallet mente at samvær burde nektes fordi det forelå en risiko for negative konsekvenser for datteren.

I den andre saken ${ }^{58}$ var det spørsmål om endring av en rettskraftig dom fra 2015 hvor mor hadde blitt tildelt foreldreansvaret alene, og far hadde fått begrenset samvær for partenes syv år gamle datter. Mor anførte for lagmannsretten at denne saken hadde likhetstrekk med det som blant annet fremgår av avsnitt 48 i Rt-2013-1329 om svekket omsorgsevne hos bostedforelderen.

Lagmannsretten kom til at datteren skulle ha beskyttet tilsyn ved samvær med far, og mor skulle fremdeles ha foreldreansvaret alene. Ved begrunnelsen for samvær og tilsyn la retten blant annet vekt på at svekket omsorgsevne hos mor ville ha negativ innflytelse på datterens omsorgssituasjon.

${ }^{58}$ LB-2016-182791. 
Den tredje saken ${ }^{59}$ omhandlet spørsmålet om foreldreansvar og samvær med partenes tre år gamle gutt. Fra mors side ble det blant annet anført:

«Det vises i den forbindelse til avgjørelser inntatt i Rt-2007-967 og Rt-2013-1329. Mor reagerer kraftig, både fysisk og psykisk, på kontakt med barnets far. Selv om hennes reaksjoner skulle bygge på vrangforestillinger, medfører dette en svekket omsorgsevne overfor gutten.» ${ }^{60}$

I lagmannsrettens bemerkninger fremgår det:

«Ved vurdering av om det er best for et barn at det ikke er samvær, kan det ifølge lovforarbeidene også få betydning om den som har barnet boende hos seg har utviklet angst for den som ønsker samvær i en slik grad at et eventuelt samvær går ut over evnen til å fungere som omsorgsperson for barnet.» ${ }^{61}$

Lagmannsretten kom til at dette ikke var tilfellet i denne saken, og at det burde være samvær. Likevel måtte omfanget av samværet fastsettes på grunnlag av forholdene slik de er i dag. Fordi far ikke hadde noen erfaring i farsrollen, og hadde et svært begrenset nettverk til rådighet for hjelp og veiledning, trengte han mer trening for å kunne fylle farsrollen. Far ble tildelt samvær én gang i uken i Åpen barnehage.

Det er kun disse 3 lagmannsrettsdommene som viser direkte til Rt. 2013 s. 1329 avsnitt 47 og 48 om at svekket omsorgsevne hos bostedsforelderen kan ha betydning ved vurdering av samvær. Likevel er det flere av dommene vi har gjennomgått, som drøfter betydningen av hvordan samvær kan virke inn på bostedsforelderens omsorgsevne, uten at det er referert til Rt. 2013 s. 1329. I disse dommene vises det som regel til lovforarbeidene hvor dette momentet er aktuelt. Et viktig funn i vår gjennomgang av samtlige dommer er at der spørsmålet om svekket omsorgsevne ble drøftet, med eller uten henvisning til Rt. 2013 s. 1329, var det ingen dommer som uttrykkelig drøftet hvorvidt det var mulig å avkrefte påstander om risiko for overgrep, og hvilken betydning dette kunne ha for bostedsforelderens omsorgsevne.

\subsection{Risiko for vold og overgrep}

\footnotetext{
${ }^{59}$ LE-2015-73302.

60 LE-2015-73302.

${ }^{61}$ LE-2015-73302.
} 
Det er $2^{62}$ av de 16 lagmannsrettsdommene som viser til Rt. 2013 s. 1329 i tilknytning til vurdering av risiko for overgrep. Den ene saken ${ }^{63}$ gjaldt spørsmålet om samvær mellom far og sønnen på 12 år og datteren på 11 år. Tingretten kom til at det ikke skulle være samvær fordi det forelå reell risiko for overgrep fra far mot datter. Den sakkyndige som var oppnevnt for tingretten, hadde fått i mandat blant annet særlig å vurdere risikoen for seksuelle overgrep fra far. Retten viste her til Rt. 2013 s. 1329 som ble vedlagt dokumentene til den sakkyndige. ${ }^{64}$ I sin skriftlige erklæring presenterte den sakkyndige to risikovurderinger basert på to ulike faktiske forutsetninger, uten å konkludere med om overgrep faktisk hadde skjedd eller ikke. Deretter ga han en anbefaling med hensyn til omfanget av samvær under forutsetning av at retten ikke fant at det var reell risiko for fremtidige overgrep. I behandlingen av denne saken for lagmannsretten ble det ikke referert til høyesterettsdommen fra 2013. Ved spørsmålet om det forelå en reell risiko for overgrep fra far, viste retten til den sakkyndiges erklæring for tingretten, og konkluderte med at det ikke forelå holdepunkter for at far hadde begått uønskede seksuelle handlinger mot noen av sine barn.

I denne lagmansrettsdommen vises det kun til høyesterettsdommen fra 2013 i mandatet til sakkyndige. Utover dette er det ingen henvisninger til Høyesteretts dom. Retten tar imidlertid utgangspunkt i blant annet barneloven $\S 43$ første ledd tredje punktum og $\S 48$ annet ledd i sine vurderinger, og legger til grunn at barna ikke har blitt utsatt for seksuelle overgrep, og at det heller ikke er risiko for dette i fremtiden:

«På denne bakgrunn er det etter lagmannsrettens syn ikke holdepunkter for å anta at det er reell risiko for fremtidige overgrep fra A (far) mot D eller C. Samvær skal da ikke nektes på dette grunnlag, jf. barnelova $§ 43$ første ledd og $§ 48$ annet ledd.» ${ }^{65}$

I høyesterettsdommen fra 2013 ble det konkludert med at det ikke skulle være samvær mellom far og datter, fordi risiko for overgrep ikke lot seg avkrefte, og at samvær av den grunn ville redusere mors omsorgsevne. I denne lagmannsrettsdommen berøres ikke spørsmålet om samvær vil svekke omsorgsevnen hos mor, til tross for at hun tror far har utsatt barna for overgrep, og i flere perioder har nektet ham samvær. Selv om Rt. 2013 s. 1329 ble vist til i mandatet til sakkyndige, og vedlagt sakens dokumenter, fikk vurderingene $\mathrm{i}$ høyesterettsdommen om svekket omsorgsevne fordi overgrepspåstander ikke lot seg avkrefte,

\footnotetext{
62 LF-2016-70792 og LB-2016-78872.

63 LB-2016-78872.

64 LB-2016-78872.

65 LB.2016-78872.
} 
ingen innflytelse for denne lagmannsrettsdommen. Det ble også fastsatt mer samvær enn barna ga uttrykk for at de ønsket.

Den andre lagmannsrettsdommen ${ }^{66}$ dreide seg om eventuell utvidelse av et allerede tilkjent samvær mellom far og partenes tre felles barn. Mor stilte krav om samvær med tilsyn, men lagmannsretten fant at det ikke forelå holdepunkter for at det var risiko for at far ville utøve vold mot barna under samvær. Tidligere vold mot barna fra begge parter ble av lagmannsretten vurdert som situasjonsbestemt under en konfliktfylt periode i samlivet. Mors påstand om samvær med tilsyn begrunnes med angst for far fordi han utøvde vold mot henne og barna i samlivet, og at far kan sette barna opp mot henne og dermed svekke hennes omsorgsevne. I denne dommen drøftes betydningen av samvær for mors omsorgsevne:

«Videre er det fra mors side vist til Rt-2013-1329. I saken Høyesterett behandlet ble mors angst for far tillagt vekt ved vurdering av samvær, fordi det ikke lot seg avkrefte at det forelå risiko for seksuelt overgrep fra fars side. Det er ikke situasjonen i vår sak. Her stiller mor krav om tilsyn ut fra et kontrollbehov som ikke fremstår som fornuftig fundert. Saken fra Høyesterett gjaldt dessuten spørsmål om samværsnekt.»

Høyesterettsdommen gir liten veiledning med hensyn til hvor listen skal legges for å sannsynliggjøre risiko for overgrep. Dette kan kanskje forklare at svært få av dommene vi gjennomgikk hvor lagmannsretten foretok en konkret vurdering av risiko for overgrep, valgte å knytte disse risikovurderingene til Rt-2013-1329.

\subsection{Konkret vurdering på grunnlag av forholdene i dag}

I $2^{67}$ av de 16 lagmannsrettsdommene som refererer til høyesterettsdommen fra 2013, er det vist til avsnitt 40 i denne dommen. Det var i dette avsnittet Høyesterett fastslo at vurderingen om samvær skulle skje på grunnlag av forholdene i dag.

I den ene saken ${ }^{68}$ var spørsmålet om retten skulle fastsette samvær mellom far og de yngste barna på 12 og 10 år. Her bemerker retten:

«Når lagmannsretten med dette som utgangspunkt går over til den konkrete vurderingen av om det skal være samvær mellom A og partenes to yngste barn, skal

\footnotetext{
${ }^{66}$ LF-2016-70792.

67 LF-2016-149125 og LB-2016-19954.

68 LF-2016-149125.
} 
vurderingen skje på grunnlag av forholdene i dag og hva som vil fremstå som best for barna fremover i tid, jf. Rt-2013-1329 avsnitt 40 ...»

Etter en helhetsvurdering av blant annet barnas omsorgsbehov og deres ønsker, konflikten mellom partene, fars samværskompetanse, risiko for vold og betydningen av samvær for mors omsorgsevne konkluderte retten med at det skulle være samvær mellom far og barn. På grunn av det høye konfliktnivået mellom foreldrene og barnas behov for ro og stabilitet kunne det ikke fastsettes et så omfattende samvær som barna ønsket.

Den andre dommen ${ }^{69}$ dreide seg om samvær mellom mor og datteren på 8 år. Moren hadde slitt med rus og psykiske problemer i lang tid. Datteren ønsket samvær med mor, men bare så lenge hun var frisk. Selv om mor nå var under behandling, mente lagmannsretten at det var for stor usikkerhet knyttet til mors diagnose og prognose, og at det derfor ikke kunne fastsettes samvær.

Også denne dommen viser både til at vurderinger skal ta utgangspunkt i situasjonen her og nå, og at tungtveiende grunner ikke er noe tilleggsvilkår, med henvisning til høyesterettsdommen fra 2013.

I tillegg til disse to lagmannsrettsdommene var det kun et par dommer til som uttrykkelig baserte avgjørelser om samvær på situasjonen her og nå, da uten referanse til Rt. 2013 s. 1329.

\section{Avslutning}

Som tidligere redegjort for fikk vi 56 treff på lagmannsrettsdommer med referanse til Rt. 2013 s. 1329 ved vårt søk i Lovdata 18. september 2017. Ved nytt søk nesten et år senere, 5. september 2018, fikk vi 73 treff. Denne høyesterettsdommen blir vist til i stor grad i saker hvor vold og overgrep er et vurderingstema. Dommen har fremdeles aktualitet, ikke minst fordi det ikke er avsagt noen nyere høyesterettsdommer med lignende vurderingstema. Det foreligger interessante funn og tendenser som kan utledes av analysen vi har foretatt.

I forarbeidene til endringene i barneloven ble det lagt til grunn at forslagene samlet sett ville bidra til å senke terskelen for avgjørelser om at det ikke skal være samvær. Dette følges opp i Rt. 2013 s. 1329 hvor det i avsnitt 41 etter gjennomgang av de sentrale momenter fra

\footnotetext{
${ }^{69}$ LB-2016-19954.
} 
barneloven og forarbeider ved vurdering av samvær sies eksplisitt at Høyesterett har hatt en lavere terskel for vurdering av samværsnekt enn lagmannsretten i samme sak:

«Den samla lagmannsretten har lagt til grunn ein noko høgare terskel for at det ikkje skal vere samværsrett for far enn det eg no har gjort greie for. Men trass i dette kom fleirtalet i lagmannsretten til at far ikkje skulle ha samvær med D.»

Ser vi lagmannsrettsdommene samlet, fant retten at samvær skulle nektes i 7 av de 16 dommene. Det var kun 4 dommer hvor retten konkluderte med at det skulle være samvær uten tilsyn, og i resten ble det fastsatt samvær med tilsyn. Dette kan tyde på at lagmannsrettene har fulgt opp intensjonen i lovforarbeidene om at terskelen for å nekte samvær burde senkes.

Tidligere forelå det fast praksis om at det skulle ganske mye til for å nekte samvær etter barneloven. Det ble oppstilt et tilleggsvilkår om «ganske tungtveiende grunner». I Prop. 85 L (2012-2013) fastslås det at «tungtveiende grunner» ikke skal være et tilleggsvilkår. Som vi har sett, bekreftet førstvoterende dette i Rt. 2013 s. 1329 avsnitt 39 og gikk dermed vekk fra tidligere rettspraksis hvor tungtveiende grunner ble ansett som et tilleggsvilkår. I vår analyse av lagmannsrettsdommer hvor det har blitt referert til høyesterettsdommen fra 2013, er det avsnitt 39 om at tungtveiende grunner ikke skal være et tilleggsvilkår, som er mest fremtredende. Dette kan tyde på at Rt. 2013 s. 1329 har hatt stor prejudikatverdi når det gjelder dette momentet. Dette forsterkes ytterligere i lagmannsrettsdommene som viser til avsnitt 33 i høyesterettsdommen der det sies at regelen om at samvær ikke skal fastsettes dersom det ikke er til barnets beste, er en absolutt regel.

Også momentet fra forarbeidene om at situasjonen her og nå bør tillegges økt vekt, som vår høyesterettsdom valgte å legge til grunn for vurderinger av samvær, har delvis blitt fulgt opp i et par av lagmannsrettsdommene, men her er bildet mer uklart, og det er vanskelig å si noe om prejudikatverdien av premiss 40 i Rt. 2013 s. 1329.

Rt. 2013 s. 1329 representerer et klart skifte i Høyesteretts vektlegging av risiko for overgrep. Selv om retten fant at det ikke forelå tilstrekkelig grad av sannsynlighet for at far hadde utsatt stedatteren for overgrep, og det videre ble lagt til grunn at han ikke hadde utsatt fellesbarnet for overgrep, ble påstander om overgrep tillagt vekt. Så lenge det ikke lot seg gjøre å avkrefte risiko, ville dette ha negativ innvirkning på mors omsorgsevne. I helhetsvurderingen av samvær ble dette utslagsgivende for samværsnekt. I vår analyse er det ingen av lagmannsrettsdommene som har vurdert bostedsforelderens omsorgsevne ut fra om risiko for 
overgrep lar seg avkrefte. Det ser dermed ut til at underrettspraksis har utvist forsiktighet med å legge dette momentet til grunn for vurdering av samvær, og følgelig at Rt. 2013 s. 1329 har hatt liten eller ingen prejudikatverdi på dette punktet.

Som tidligere nevnt var det kun i 5 av lagmannsrettsdommene at en av eller begge partene viste til Rt. 2013 s. 1329 i sine anførsler. Det er verdt å merke seg at det derfor i hovedsak er lagmannsrettene selv som har vist til høyesterettsdommen fra 2013. Vi hadde nok forventet at partene i saken, særlig den som fremmer påstand om samværsnekt, i større grad ville vist til de aktuelle avsnittene i høyesterettsdommen.

I Backers kommentarutgave til barneloven ${ }^{70}$ fremholdes at dommer fra Høyesterett har en begrenset prejudikatverdi i saker etter barneloven. Lignende synspunkt blir også fremholdt av Bendiksen og Haugli. ${ }^{71}$ Vår gjennomgang av lagmannsrettsavgjørelser der det har blitt vist til Rt. 2013 s. 1329, bekrefter rettsteorien på dette punktet. Noen av momentene fra høyesterettsdommen har fått større innflytelse for senere lagmannsrettspraksis enn andre. Det ser dermed ut til at lagmannsrettene fastholder retten til å utøve skjønn basert på helhetsvurderinger av aktuelle momenter i de konkrete sakene.

Hovedinntrykket vårt er at høyesterettsdommen har hatt større betydning når det gjelder rettsavklaring enn rettsutvikling. Dersom avsnitt 48 i dommen, hvor det ble lagt vekt på at risiko for overgrep ikke lot seg avkrefte, og dermed kunne bidra til å svekke mors omsorgsevne, hadde satt tydelige spor i lagmannsrettspraksis, ville konklusjonen vært at Rt. 2013 s. 1329 også har bidratt til rettsutvikling. Vår analyse av dommer er imidlertid begrenset til en bestemt periode, og det har kommet flere nyere lagmannsrettsdommer med henvisninger til denne høyesterettsdommen. Det kan derfor ikke utelukkes at bildet i dag ser noe annerledes ut.

\footnotetext{
${ }^{70}$ Backer, I.L. (2017b), s. 337.

${ }^{71}$ Bendiksen, L.R.L. og Haugli, T. (2015), s. 33.
} 